\title{
DIET OF CROTALUS ENYO (SERPENTES: VIPERIDAE) FROM THE BAJA CALIFORNIA CAPE REGION, MEXICO
}

\author{
Rubén A. CARbajal-MÁRQUEZ, ${ }^{1, *}$ Gustavo ARNAUd, ${ }^{1}$ Marcio MARTINS ${ }^{2}$ \\ \& GuSTAVO E. QUINTERO-DÍAZ ${ }^{3}$
}

\begin{abstract}
${ }^{1}$ Centro de Investigaciones Biológicas del Noroeste, S.C., Instituto Politécnico Nacional 195, Col. Playa Palo de Santa Rita Sur, La Paz, Baja California Sur, México, C. P. 23096. *Corresponding author. e-mail: <redman031@hotmail>

${ }^{2}$ Departamento de Ecologia, Instituto de Biociências, Universidade de São Paulo, 05508-090, São Paulo SP, Brasil, C. P. 1146.

${ }^{3}$ Departamento de Biología, Centro de Ciencias Básicas, Universidad Autónoma de Aguascalientes, Av. Universidad 940, Ciudad Universitaria, C.P. 20131. Aguascalientes, Aguascalientes, México.
\end{abstract}

Recibido: 14/04/2015; aceptado: 27/01/2016

\begin{abstract}
Carbajal-Márquez, R. A., Arnaud, G., Martins, M. \& QuinteroDíaz, G. E. 2016. Diet of Crotalus enyo (Serpentes: Viperidae) from the Baja California cape region, Mexico. Acta Zoológica Mexicana (n. s.), 32(1): 45-48.
\end{abstract}

\begin{abstract}
Crotalus enyo is a rattlesnake endemic to Baja California peninsula, Mexico. The natural history of this species is poorly known, so the goal of this study was to determine the diet of $C$. enyo in the Cape Region, an area with different conditions than the rest of the peninsula. We analyzed the stomach contents of 24 specimens obtained during 2010-2013, and identified the ingested prey. The diet of C. enyo consists of rodents (83.34\%) and lizards (16.66\%), although presents a diverse diet, the data suggest $C$. enyo is a specialist predator at Cape Region. We didn't find differences in diet composition between sexes, site of capture, or season. This study documents three new prey items in the diet of $C$. enyo: the Orange-Throated Whiptail (Aspidocelis hyperythra), the Cape Spiny-Tailed Iguana (Ctenosaura hemilopha) and Hunsaker's Spiny Lizard (Sceloporus hunsakerii).

Key words: Rattlesnake, Aspidocelis hyperythra, Ctenosaura hemilopha, Sceloporus hunsakerii, endemic, Peninsula.
\end{abstract}

\section{INTRODUCTION}

The Baja California Rattlesnake, Crotalus enyo, is endemic to the Baja California peninsula, Mexico and listed in the category of threatened in the NOM-059-SEMARNAT-2010 (Diario Oficial de la Federación 2010). It's a stout, moderate-sized snake, with a small head, large eyes, and the outer edges of the supraocular scales noticeably elevated. It's distributed throughout most of the Baja California peninsula, the Pacific islands of Magdalena and Santa Margarita, and the Gulf of California islands of Carmen, Cerralvo, Coronados, Espiritu Santo, Pardo, Partida
Carbajal-Márquez, R. A., Arnaud, G., Martins, M. \& QuinteroDíaz, G. E. 2016. Dieta de Crotalus enyo (Serpentes: Viperidae), en la región del cabo, Baja California, México. Acta Zoológica Mexicana (n. s.), 32(1): 45-48.

RESUMEN. Crotalus enyo es una víbora de cascabel endémica de la península de Baja California, México. La historia natural de ésta especie es poco conocida, por lo cual el objetivo de éste estudio fue determinar la dieta de $C$. enyo en la Región del Cabo, que presenta condiciones particularmente distintas al resto de la península. Se analizaron los contenidos estomacales de 24 especímenes obtenidos durante 2010-2013, y se identificaron las presas ingeridas. La dieta de C. enyo consiste en roedores (83.34\%) y lagartijas (16.66\%), y aunque presenta una dieta diversa, los datos sugieren que C. enyo es un depredador especialista en la Región del Cabo. No se encontró diferencia en la composición de la dieta entre sexos, sitios de captura y temporadas. Este estudio documenta tres nuevos elementos en la dieta de C. enyo: el Huico Garganta Naranja (Aspidocelis hyperythra), el Garrobo del Cabo (Ctenosaura hemilopha) y la Lagartija Espinosa de Hunsaker (Sceloporus hunsakerii).

Palabras clave: Víbora de cascabel, Aspidocelis hyperythra, Ctenosaura hemilopha, Sceloporus hunsakerii, endémica, Península.

Sur, San Francisco, San Jose and San Marcos (Grismer 2002). Little is known about the natural history of this species; previously Taylor (2001) reported on the diet of $C$. enyo based on museum specimens collected from most of its distribution, finding that it feeds mainly on mammals, followed by reptiles and centipedes. Here we examine the diet of $C$. enyo from within the Cape region, which comprises the western boundary of tropical dry forest in the northern hemisphere, hosts the Miocene remnants of tropical vegetation from the continental portion of Mexico, and has different weather conditions than the rest of the peninsula (Arriaga 2010; González-Abraham et al. 2010). 


\section{MATERIAL AND METHODS}

We conducted 39 visits at different localities at Cape Region, Baja California Sur (southern region of the peninsula, from the Isthmus of La Paz, south to San Jose del Cabo), accumulating 215 hours of search, and 72 night road transects accumulating $8472 \mathrm{~km}$, from July 2010 to July 2012 and found 21 snakes (16 dead on road (DOR), and five alive); additionally we found three DOR snakes between June- July 2013. Captured snakes were searched for stomach contents and feces, which we obtained by forced regurgitation and gentle palpation of the last third of the body, respectively. In the case of salvaged snakes, found DOR, we checked for stomach and hindgut contents by making a ventral incision. We recorded snout-vent length (SVL), sex, and site of capture of each snake. Prey samples were preserved in alcohol (70\%). Lizard scales were identified by comparison with a reference collection of the reptiles from Baja California Sur, in the Laboratory of Animal Ecology at Centro de Investigaciones Biológicas del Noroeste (CIBNOR), and the remains of mammals, with hair preparations of rodent species present in the Cape Region and the literature (Whorley 2000). Live specimens were released and the DOR specimens were deposited in the Herpetological Collection at CIBNOR (CIB1373, CIB1390, CIB1430, CIB1431, CIB1434, CIB1437, CIB1439, CIB1446, CIB1452).

We tested for differences in diet composition between sexes, site of capture (desert scrub vs. dry forest) and seasons (dry vs. rainy) by comparing the frequencies of prey types with Chi-square test. We tested difference between the SVL of snakes and prey taxon, and with multiple and single prey items using a Mann-Whitney U-test. We analyzed seasonal differences in foraging activity by comparing the proportion of snakes with stomach contents between the dry and rainy season with Chi-square test. We tasted for differences in SVL between males and females using a Mann-Whitney U-test. Statistica 7.1 (Statsoft 2005) was used for all statistical procedures following Avila-Villegas et al. (2007).

\section{RESULTS}

Of the 24 snakes examined (5 alive, 19 DOR), 18 (75\%) contained identifiable prey in their stomach and/ or hindguts, and six had no contents. Twenty prey items were found: 16 Spiny Pocket Mouse (Chaetodipus spinatus), two Cape Spiny-Tailed Iguana (Ctenosaura hemilopha) one Hunsaker's Spiny Lizard (Sceloporus hunsakerii), and one Orange- Throated Whiptail (Aspidocelis hyperythra). In two cases, remains of two different prey species were found in the same sample: both with $C$. spinatus and C. hemilopha (Table 1). Our sample ranges from 410-744 SVL with average of $608.9 \mathrm{~mm}(s d= \pm 92.7 ; \mathrm{n}=24)$.

There were no significant differences in diet composition between sexes $\left(\right.$ male $=14$, female $=4 ; \chi^{2}=0.0, d f=$ $1, P=1.0)$, season $\left(\right.$ dry $=5$, rainy $=13 ; \chi^{2}=0.0, d f=1, P$ $=1.0$ ) or site of capture (desert scrub $=3$, dry forest $=15$; $\left.\chi^{2}=0.08, d f=1, \mathrm{P}>0.05\right)$. The SVL of the snakes that feed on mammals range from $410-744 \mathrm{~mm}$, with average of $592.5 \mathrm{~mm}(s d= \pm 104.8 \mathrm{~mm} ; n=16)$, and of snakes that feed on lizards of $620-690 \mathrm{~mm}$, with average of 654.2 $\mathrm{mm}(s d= \pm 36.3 \mathrm{~mm} ; n=4)$ (Fig. 1). No differences in SVL were found between the snakes that consumed mammals compared to reptiles $(Z=-1.05, P>0.05)$, therefore there is no appreciable ontogenetic shift. Snakes with multiple prey items average $658 \mathrm{~mm}(s d= \pm 45.2 ; n=$ $2)$, and snakes with single prey average $591.6 \mathrm{~mm}(\mathrm{sd}$ $= \pm 104.2 ; \mathrm{n}=16$ ), no differences in SVL were found between these two groups $(Z=-0.98, P>0.05)$. The proportion of snakes with food items did not differ between

Table 1. Frequency of occurrence of prey types in stomach contents and feces of Crotalus enyo. (*One sample with two types of prey).

\begin{tabular}{lcccc}
\hline & $\begin{array}{c}\text { Stomach } \\
\text { contents }\end{array}$ & Feces & Total & $\%$ \\
\hline Mammals & 2 & $13^{*}$ & 15 & $\mathbf{8 3 . 3 4}$ \\
Chaetodipus spinatus & 0 & 16 & $\mathbf{3}$ & $\mathbf{1 6 . 6 6}$ \\
Reptiles & 0 & 1 & 2 & \\
Ctenosaura hemilopha & 0 & 1 & 1 & \\
Sceloporus hunsakerii & 2 & 16 & 1 & \\
Aspidocelis hyperythra & & & $\mathbf{1 8}$ & $\mathbf{1 0 0}$ \\
Total & & & & \\
\hline
\end{tabular}




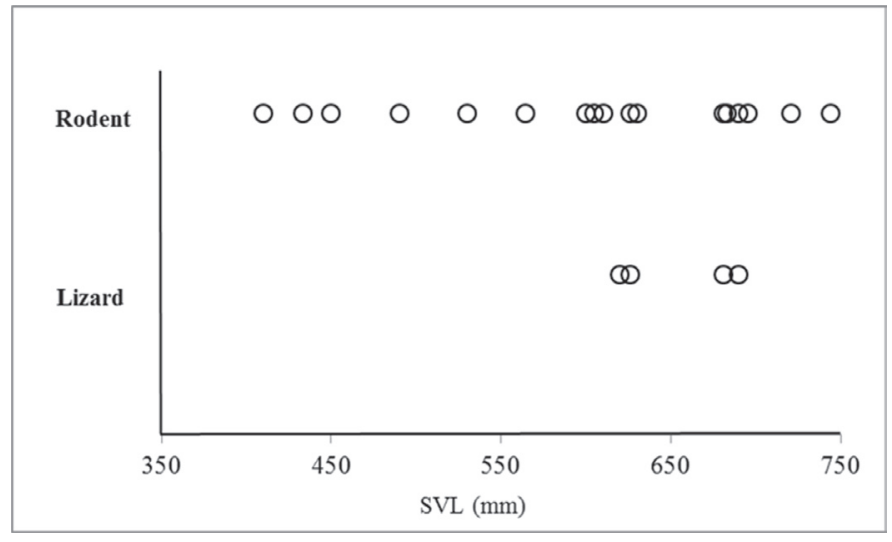

Figure 1. Crotalus enyo snout-vent length (SVL) vs. prey type at Cape Region.

dry (February-July; $\mathrm{n}=5$ ) and rainy (August-January; $n=$ 13) season $\left(\chi^{2}=0.87, d f=1, P>0.05\right)$. The range of SVL on adult males was $618.4 \mathrm{~mm}(s d= \pm 90.0)$ and SVL on adult females $572.8 \mathrm{~mm}(s d= \pm 104.3)$. The difference in SVL between males and females was not significant $(Z=$ $1.03, P>0.05$; males $=19$, females $=5$ ).

\section{DISCUSSION}

The diet of $C$. enyo is similar to that of other snakes of the same genus that feed primarily on mammals, reptiles and to lesser extent arthropods (Taylor 2001; Clark 2002; Holycross et al. 2002; Ávila-Villegas et al. 2007; Dugan $\&$ Hayes 2012). The most common prey item is the rodent C. spinatus, which make up $83.34 \%$ of the prey items and are frequently observed during nocturnal walking transects. Taylor (2001) mentions the high frequency of Chaetodipus sp. is probably a result of the easy of identifying this genus compared to other rodents. We suggest the high intake of Chaetodipus spinatus in our samples, may be the result that is a small and abundant rodent, easier to swallow, in relation to the small and slender head characteristic of C. enyo, this also applies to lizards (Klauber 1931; Meik et al. 2010). Lizards accounted for $16.66 \%$ of prey items, with three species that had not been recorded previously in the diet: Ctenosaura hemilopha and Sceloporus hunsakerii, both restricted to the southern portion of the peninsula, and Aspidocelis hyperythra found throughout the distribution of $C$. enyo. The latter two prey items were been reported to the genus level (Sceloporus sp. and Aspidocelis sp.), but had not been identified to species (Taylor 2001; Grismer 2002).
Taylor (2001) mentioned C. enyo is a generalist snake as it feeds on a wide variety of rodents, lizards and centipedes of genus Scolopendra sp., but centipedes were not recorded in our study. The high intake of rodents indicates a preference for these mammals, so we suggest $C$. enyo is not a diet generalist, at least in the Cape Region. The intake of the $C$. hemilopha is because they were juveniles, which are about the size of an adult Sceloporus sp.

Taylor (2001) noted that there is an ontogenetic shift in the diet of $C$. enyo, where juveniles feed on reptiles and adults feed on mammals, this could not be compared because the sample obtained in this study was comprised of $100 \%$ of adult snakes. Although our results show no differences in SVL between snakes that feed on lizards or mammals, so even as adults consume lizards. Of 63 individuals with contents analyzed by Taylor (2001), 13 contained multiple preys, of which seven contained a one lizard and one mammal. In this study, only two snakes had two types of prey, a lizard and a mammal in each $(C$. spinatus and C. hemilopha), and we did not found differences between SVL of snakes with multiple prey items and snakes with single prey item, but we note the snakes that consume multiple preys to be larger than snakes with single prey, in concordance with Taylor (2001).

Crotalus enyo did not present significant difference in foraging period between the dry and rainy seasons, although we observed an increased frequency of capture in the rainy season, which coincides with the increased activity of the species of lizards preyed (Grismer 2002) (Fig. 2). We also did not found any differences based on grouping capture sites (desert scrub vs. dry forest), probably because the species consumed are widespread and are found in both vegetation types. Most rattlesnakes are sexually dimorphic in size (Klauber 1972), Taylor (2001) noted that males of $C$. enyo are significantly larger than females, but in our case we did not found these trend, maybe due to the sample size. We did not found difference in diet composition between sexes, also noticed by Taylor (2001).

With these new additions, the diet of $C$. enyo is comprised by 10 genera and 13 species, one centipede (Scolopendra sp.), five mammals (Chaetodipus spinatus, Chaetodipus sp., Dipodomys sp., Peromyscus sp. and Thomomys bottae) and seven lizards (Aspidocelis hyperythra, Aspidocelis sp. Ctenosaura hemilopha, Dipsosaurus dorsalis, Sceloporus hunsakerii, Sceloporus sp., and Uta stansburiana). We observed that prey consumed by $C$. enyo are small and slender animals that can be swallow easily like centipedes, small lizards and rodents, due 


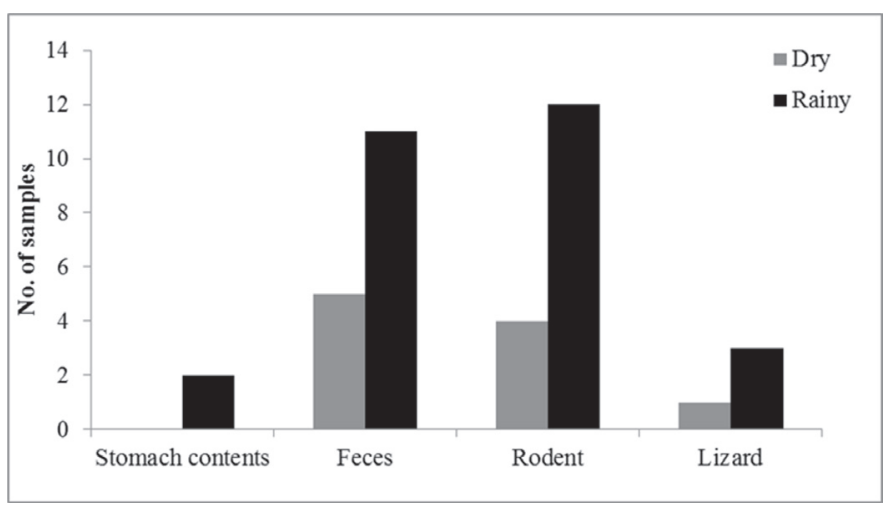

Figure 2. Foraging period and diet composition of Crotalus enyo between 2010-2013 at Cape Region.

to the small size of the head resulting in a gape-limited predator (Klauber 1931; Meik et al. 2010); the only two species that cause doubt is T. bottae by its size, but Taylor (2001) mentioned these were two nestling gophers, and in the case of $C$. hemilopha were juveniles. So the ontogenetic shift observed by Taylor (2001) probably can be explained because lizards were easier to swallow when the rattlesnakes were juveniles and have a reduced gape size.

It is well known the value of the specimens deposited in museums for research support, and particularly in the case of rare or little known species. But for detailed information on the habits of some species, it is necessary to observe and follow these animals in the nature. Although 44 of the 113 specimens analyzed by Taylor (2001) were collected within Cape Region, between the years 18821984, A. hyperytrha, C. hemilopha and S. hunsakerii were not recorded as prey of $C$. enyo. This reinforces the importance of ecological studies with greater search effort, covering many types of vegetation and the full annual cycle in subsequent years.

ACKNOWLEDGMENTS. We thank Consejo Nacional de Ciencia y Tecnología (CONACYT) for financial support of this investigation and Centro de Investigaciones Biológicas del Noroeste, S.C. (CIBNOR) provided institutional help. We thank Jorge H. Valdéz Villavicencio for help in identifying lizards and road transect monitoring. We thank the people who helped us in field work and laboratory, especially P. Galina Tessaro, F. Cota, A. Cota, J. M. Rodríguez Canseco, M. Matus Hernández, O. Cruz, E. Méndez Salinas, R. Domínguez Cadena, I. Guerrero Cárdenas and P. Lucero Geraldo. Permits were provided by Dirección General de Vida Silvestre SEMARNAT (SGPA/DGVS/045225/11).

\section{LITERATURE CITED}

Arriaga, L. 2010. Sierra de la Laguna, Baja California Sur. Pp. $393-$ 396. In: G. Ceballos, L. Martínez, A. García, E. Espinoza, J. Bezaury-Creel \& R. Dirzo (Eds.).Diversidad, amenazas y áreas prioritarias para la conservación de las selvas secas del Pacifico de México. Comisión Nacional de Áreas Naturales Protegidas, Fondo de Cultura Económica, Comisión Nacional para el Conocimiento y Uso de la Biodiversidad. D.F. México.

Avila-Villegas, H., Martins, M. \& Arnaud, G. 2007. Feeding Ecology of the Endemic Rattleless Rattlesnake, Crotalus catalinensis, of Santa Catalina Island, Gulf of California, Mexico. Copeia, 8084.

Clark, R. W. 2002. Diet of the Timber Rattlesnake Crotalus horridus. Journal of Herpetology, 36: 494-499.

Diario Oficial de la Federación. 2010. Norma Oficial Mexicana NOM-059-SEMARNAT-2010, Protección ambiental-Especies nativas de México de flora y fauna silvestres-Categorías de riesgo y especificaciones para su inclusión, exclusión o cambio-Lista de especies en riesgo, 30 de diciembre de 2010.

Dugan, E. A. \& Hayes, W. K. 2012. Diet and Feeding Ecology of the Red Diamond Rattlesnake, Crotalus ruber (Serpentes: Viperidae). Herpetologica, 68: 203-217.

González-Abraham, C. E., Garcillán, P. P., Ezcurra, E. y El Grupo de Trabajo de Ecorregiones. 2010. Ecorregiones de la Península de Baja California: Una Síntesis. Boletín de la Sociedad Botánica de México, 87: 69-82.

Grismer, L. L. 2002. Amphibians and Reptiles of Baja California, Including its Pacific Islands and the Islands in the Sea of Cortés. University of California Press. Berkeley.

Holycross, A. T., Painter, C. W., Prival, D. B., Swann, D. E., Schroff, M. J., Edwards T. \& Schwalbe, C. R. 2002. Diet of Crotalus lepidus klauberi (Banded Rock Rattlesnake). Journal of Herpetology, 36: 589-597.

Klauber, L. M. 1972. Rattlesnakes, their habits, life histories, and influence on mankind. 2 vols. University of California Press, Berkeley.

Klauber, L. M. 1931. Crotalus tigris and Crotalus enyo, two little known rattlesnakes of the southwest. Transactions of the San Diego Society of Natural History, VI: 353-370.

StatSoft, Inc. 2005. STATISTICA (data analysis software system). Version 7.1. http://www.statsoft.com.

Meik, J. M., Lawing, A. M. \& Pires-daSilva, A. 2010. Body Size Evolution in Insular Speckled Rattlesnakes (Viperidae: Crotalus mitchellii). PLoS ONE 5(3): e9524. doi: 10.1371/journal. pone.0009524

Taylor, E. N. 2001. Diet of the Baja California Rattlesnake, Crotalus enyo (Viperidae) Copeia, 2001(2):553-555.

Whorley, J. R. 2000. Keys to Partial Mammals: A Method for Identifying Prey Items for Snakes. Herpetological Review, 31: 227229. 